\title{
PENGEMBANGAN DAN VALIDASI METODE ANALISIS RIFAMPICIN ISONIAZID-PIRAZINAMID DALAM FIXED DOSE COMBINATION DENGAN METODE KROMATOGRAFI LAPIS TIPIS-DENSITOMETRI
}

\author{
M. Hatta Prabowo ${ }^{1 *}$, Ari Wibowo ${ }^{2}$, Laily Fauziyah ${ }^{3}$ \\ ${ }_{1,2,3}$ Program Studi Farmasi Universitas Islam Indonesia \\ *e-mail: htprabowo@gmail.com
}

\begin{abstract}
ABSTRAK
Rifampicin, isoniazid (INH) dan pirazinamid merupakan Obat Anti Tuberkulosis (OAT) yang tersedia dalam bentuk Fixed Dose Combination (FDC). Sediaan FDC ini lebih praktis dalam penggunaannya sehingga dapat meningkatkan kepatuhan pasien Tuberkulosis (TB) dalam mengkonsumsi obat. Namun pada beberapa penelitian masih ditemukan FDC yang subdosis yang dapat mengakibatkan pengobatan TB menjadi kurang optimal dan meningkatnya risiko resistensi OAT. Tujuan penelitian ini adalah mengembangkan metode analisis baru yaitu Kromatografi Lapis Tipis (KLT)Densitometri yang memiliki validitas baik sehingga dapat menjadi alternatif metode analisis yang lebih mudah, cepat, murah dan praktis. Validasi metode yang dilakukan meliputi pengukuran linieritas, presisi, akurasi, batas deteksi dan batas kuantitasi. Parameter hasil validasi metode dibandingkan dengan persyaratan yang ada di Association of Official Analytical Chemist (AOAC) dan United States Pharmacopeia (USP) untuk penetapan kadar FDC. Sampel FDC yang mengandung rifampicin, INH dan pirazinamid dapat dipisahkan dengan fase gerak berupa n-heksan: 2-propanol: aseton: amonia: asam format dengan perbandingan 3:3,6:3:0,3:0,1 (v/v/v/v) dan nilai Rf yang diperoleh untuk rifampicin adalah 0,85 , INH 0,6 dan pirazinamid 0,7 . Hasil penelitian menunjukkan bahwa metode KLTDensitometri dapat dikembangkan dan semua parameter validasinya memenuhi persyaratan AOAC. Hasil koefisien korelasi (r) rifampicin 0,999, INH 0,999 dan pirazinamida 0,999 , perolehan kembali rifampicin 101,00\%, INH 94,36\% dan pirazinamid 95,69\%; nilai \% RSD presisi rifampicin $0,55 \%$, INH $0,96 \%$, dan pirazinamid $0,98 \%$; nilai batas deteksi rifampicin 10,91 ppm, INH 10,38 ppm dan pirazinamid 42,14 ppm; nilai batas kuantitasi
\end{abstract}

rifampicin 33,07 ppm, INH 31,45 ppm dan pirazinamid 127,7 ppm. Kadar terukur (mg) rifampicin, $\mathrm{INH}$, dan pirazinamid per tablet adalah 157,37 mg, 75,26 mg dan 400,79 mg yang berarti sesuai dengan standar yang ditetapkan oleh USP.

Kata kunci: KLT-Densitometri, rifampicin$\mathrm{INH}$-pirazinamid, validasi

\section{ABSTRACT}

Rifampicin, isoniazid (INH) and pyrazinamide are anti tuberculosis drugs (ATD) available in fixed dose combination (FDC) form. The FDC is more practical in usage so can improve tuberculosis patient obedience in consuming the drug. However, in some researches, there are still found subdose of FDC. Subdose of FDC that effected in less optimal TB medication and increase risk of ATD resistance. The high TB case in developing countries such as Indonesia require test of FDC drug dose evaluation. Objective of this research was to develop new analytical method, Thin Layer Chromatography (TLC)-densitometry having good validity so it may be easier, faster, cheaper and more practical analytical method alternative. Validation parameters consist of linearity, precision, accuracy, Limit Of Detection (LOD), and Limit Of Quantitation (LOQ). Parameter of method validation results was compared with requirement in Association of Official Analytical Chemist (AOAC) and United States pharmacopeia (USP) for determine active ingredient in sample. FDC sample containing rifampicin, INH and pyrazinamide can be separated with n-hexane: 2-propanol: acetone: ammonia: formic acid with proportion of 3:3.6:3:0.3:0.1 (v/vv/v) as mobile phase and $\mathrm{Rf}$ value for rifampicin, $\mathrm{INH}$, and pyrazinamide were $0.85,0.6$, and 0.7 , respectively. The results indicated that TLC-densitometry can be developed and all 
validation parameters complied with AOAC requirements. The correlation coefficient $(r)$ of rifampicin 0.999, INH 0.999 and pyrazinamide 0.999 ; recovery of rifampicin, $\mathrm{INH}$ and pyrazinamide were $101.00 \%, 94.36$ $\%$ and $95.69 \%$, respectively. In addition, precision, \% RSD for rifampicin, INH and pyrazinamide were $0.55 \%, 0.96 \%$, and 0.98 $\%$ respectively; LOD for rifampicin, INH and pyrazinamide were $10.91 \mathrm{ppm}, 10.38 \mathrm{ppm}$ and $42.14 \mathrm{ppm}$, respectively; LOQ for rifampicin, $\mathrm{INH}$ and pyrazinamide were 33.07 ppm, $31.45 \mathrm{ppm}$ and $127.7 \mathrm{ppm}$, respectively. Concentration of rifampicin, INH and pyrazinamide in a tablet were 157.37 $\mathrm{mg}, 75.26 \mathrm{mg}$ and $400.79 \mathrm{mg}$ that comply with USP standard.

Keywords: rifampicin-isoniazid-pyrazinamide, TLC-densitometry, validation

\section{PENDAHULUAN}

$\begin{array}{rcc}\text { Hasil } & \text { survei World Health } \\ \text { Organization } & (\mathrm{WHO}) & \text { mengenai angka }\end{array}$ kejadian TB di 22 negara, diketahui India, Cina dan Indonesia berkontribusi lebih dari $50 \%$ dari seluruh kasus TB. Indonesia menempati urutan ke-3 setelah India dan Cina (Anonim, 2008). Tingginya kasus TB di Indonesia membuat Departemen Kesehatan RI mencanangkan program bebas TB 2050.
Rifampicin, isoniazid (INH) dan pirazinamid merupakan Obat Anti Tuberkulosis (OAT) lini pertama yang digunakan untuk pengatasan penyakit TB. Ketiga obat ini tersedia dalam bentuk kombinasi satu sediaan obat dengan dosis sesuai standar yang disebut sediaan Fixed Dose Combination (FDC). Bentuk sediaan ini didesain untuk mencegah terjadinya resistensi OAT pada pasien TB, khususnya pasien dengan tingkat kepatuhan minum obat rendah yang disebabkan akibat pasien harus mengkonsumsi bermacammacam obat dalam waktu yang cukup lama sehingga banyak pasien TB yang tidak dapat menyelesaikan pengobatan hingga tahap akhir (Peloquin, 2007).

Namun yang menjadi masalah adalah banyak sediaan FDC yang beredar di masyarakat memiliki dosis dibawah standar. Fenomena ini tidak hanya terjadi di dalam negeri namun juga di luar negeri. Berdasarkan hasil penelitian yang dilakukan oleh Food Drug Administration (FDA) diketahui bahwa $31 \%$ FDC OAT yang telah beredar di pasaran Amerika ternyata subdosis (Kenyon, et al.,1999).

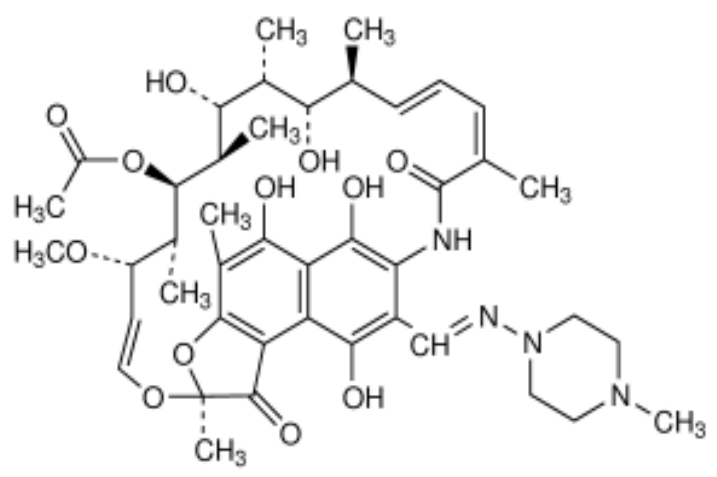

(a) 
<smiles>NNC(=O)c1ccncc1</smiles>

(b)<smiles>NC(=O)c1cnccn1</smiles>

(c)

Gambar 1. (a) Struktur kimia rifampicin , (b) Struktur kimia INH, (c) Strutur kimia pirazinamid

Metode analisis sediaan FDC yang umum digunakan saat ini mengunakan metode yang mengacu ke United State Pharmacopeia (USP) 30 untuk menganalisis rifampicin, INH dan pirazinamid dalam sediaan FDC OAT adalah metode High Performance Liquid Chromatography (HPLC) (Khuhawar, et al.,1998 dan Anonim, 2006). Namun, HPLC memiliki beberapa keterbatasan antara lain preparasi sampel yang cukup sulit, membutuhkan waktu yang lama, peralatan yang rumit dan perawatan alat yang sulit sehingga biaya yang dibutuhkan dalam penggunaan alat ini cukup tinggi (Kenyon et al, 1999), identifikasi senyawa dan sulitnya didapatkan hasil resolusi yang baik jika sampel yang dianalisis sangat kompleks (Rohman, 2007).

Penelitian dengan metode KLT untuk menganalisis campuran rifampicin, INH dan pirazinamid dalam sediaan FDC OAT meliputi analisis kualitatif dan kuantitatif. Analisa campuran antibiotik rifampicin, INH dan pirazinamid dalam sediaan FDC OAT ini dinilai penting untuk memastikan kandungan obat tersebut sesuai atau tidak dengan ketentuan yang telah ditetapkan dalam United States Pharmacopeia (USP) sehingga dapat menghindari adanya FDC OAT yang subdosis. FDC OAT yang tidak subdosis dan sesuai dengan ketentuan yang telah ditetapkan terkait kandungan zat aktifnya diharapkan dapat mengoptimalkan pengobatan TB dan menurunkan angka resistensi OAT pada pasien TB (Kelesidis,et al., 2007).

WHO merekomendasikan metode analisa yang memiliki keunggulan seperti HPLC terkait keakuratan dalam hal pemisahan senyawa dengan sensitivitas dan selektivitas yang tinggi, memiliki cara preparasi yang mudah, waktu pengerjaan yang singkat, perawatan alat yang mudah serta biaya yang lebih rendah yaitu metode Kromatografi Lapis Tipis (KLT)-Densitometri (Anonim, 2002 ${ }^{\mathrm{b}}$ ). Metode ini merupakan metode alternatif yang perlu untuk dikembangkan dalam rangka melakukan analisa campuran obat dalam FDC. Metode yang dikembangkan harus divalidasi terlebih dahulu untuk menjamin bahwa metode analisa tersebut akurat, spesifik, reprodusibel dan tahan pada kisaran analit yang akan dianalisa. Metode KLTDensitometri diharapkan menjadi solusi dari anjuran WHO akan perlunya metode yang baik, valid, mudah preparasinya, namun hasil yang didapatkan dapat dipertanggungjawabkan sehingga dapat digunakan disetiap negara baik yang maju ataupun berkembang.

\section{METODE PENELITIAN}

Bahan yang digunakan dalam penelitian ini adalah asam asetat glasial, $\mathrm{n}$ heksan, 2-propanol, aseton, ammonia, asam 
format (kualitas analisis, E. Merck), toluen, metanol (kualitas kromatografi, E. Merck), rifampicin, isoniazid (INH), pirazinamid, sampel FDC yang mengandung $150 \mathrm{mg}$ rifampicin $75 \mathrm{mg}$ isoniazid dan $400 \mathrm{mg}$ pirazinamid, plat silika gel $60 \mathrm{~F}_{254}$ (E. Merck), kertas saring (Whatman, diameter $12,5 \mathrm{~cm}$, ukuran pori $0,42 \mu \mathrm{m})$. Alat yang digunakan dalam penelitian ini adalah timbangan analitik (Mettler Toledo, kepekaan 0,0001 g), pipet tetes, pipet volume (Pyrex), propipet, labu ukur (Pyrex), gelas ukur (Pyrex), Erlenmeyer (Pyrex), mortir dan stamper,

corong gelas, chamber (ukuran $20 \times 20 \mathrm{~cm}$, Camag), Linomat 5 (tipe 130140, Camag), TLC scanner 3 (tipe 100914, Camag), Ultrasonicator (tipe B-2510, Bransonic).

\section{Optimasi eluen untuk pemisahan}

Optimasi eluen untuk proses
pemisahan dilakukan dengan menguji
cobakan beberapa eluen untuk pemisahan
senyawa rifampicin, INH dan pirazinamid
dalam sediaan FDC OAT. Eluen yang
digunakan dalam optimasi eluen dapat dilihat
pada Tabel 1.

Tabel 1. Kombinasi eluen yang digunakan dalam optimasi eluen untuk pemisahan senyawa rifampicin, INH dan pirazinamid dalam sediaan FDC OAT

\begin{tabular}{cccc}
\hline No & Kombinasi eluen & $\begin{array}{c}\text { Perbandingan } \\
\text { konsentrasi }(\% \text { v/v) }\end{array}$ & $\begin{array}{c}\text { Indeks } \\
\text { polaritas }\end{array}$ \\
\hline 1 & Metanol: aseton: amonia & $4,2: 5,5: 0,3$ & 4,95 \\
2 & Aseton: asam asetat glasial & $9,9: 0,1$ & 5,2 \\
3 & Metanol: toluen: amonia & $5,3: 4,4: 0,3$ & 3,76 \\
4 & n- heksan: 2-propanol & $5: 5$ & 2 \\
5 & n- heksan: 2-propanol: aseton & $4: 4: 2$ & 2,62 \\
6 & n- heksan: 2-propanol: aseton & $3: 3: 4$ & 3,24 \\
7 & n-heksan: 2-propanol: aseton: amonia & $3: 3: 3: 1$ & 2,73 \\
8 & n-heksan: 2-propanol: aseton: amonia: asam format & $3: 3,8: 2,8: 0,3: 0,1$ & 2,94 \\
9 & n-heksan: 2-propanol: aseton: amonia: asam format & $3: 3,6: 3: 0,3: 0,1$ & 2,96 \\
10 & n-heksan: 2-propanol: aseton: amonia: asam format & $3: 4: 2,6: 0,3: 0,1$ & 2,92 \\
\hline
\end{tabular}

\section{Preparasi larutan standar campuran}

Larutan stok standar/baku campuran rifampicin dan $\mathrm{INH}$ dengan konsentrasi 2500 ppm serta pirazinamid 5000 ppm, dibuat dengan cara melarutkan standar pro analisa rifampicin dan $\mathrm{INH}$ masing-masing $125 \mathrm{mg}$ dan $250 \mathrm{mg}$ pirazinamid dalam $25 \mathrm{~mL}$ metanol, kemudian di-ultrasonic selama 5 menit, ditambahkan metanol hingga $50,0 \mathrm{~mL}$ lalu di-ultrasonic kembali selama 5 menit.

\section{Penentuan panjang gelombang maksimal ( $\lambda$ max ) dan linieritas kurva baku}

Optimasi $\lambda$ max dilakukan dengan cara scanning $\lambda$ max dari spot kurva baku campuran rifampicin, INH dan pirazinamid di permukaan plat silika dengan menggunakan detektor UV yang terdapat dalam densitometer. Larutan stok kurva baku campuran rifampicin dan $\mathrm{INH}$ dengan konsentrasi 2500 ppm serta pirazinamid 5000 ppm diencerkan dengan metanol untuk membuat seri kadar dengan konsentrasi 50 , 100, 200, 300 dan 400 ppm untuk rifampicin dan INH serta 100, 200, 400, 600 dan 800 ppm pirazinamid. Untuk pembuatan kurva baku di buat dengan menotolkan sebanyak 5 $\mu \mathrm{L}$ seri kadar kurva baku campuran pada plat silika gel $60 \quad \mathrm{~F}_{254}$, kemudian dielusi dengan eluen terbaik sampai tanda batas atas dan dikeringkan dengan cara dianginanginkan di suhu kamar. Spot yang telah terpisah dianalisa dengan densitometer, sehingga akan didapat data Retardation factor (Rf) dan Area Under Curve (AUC). 
Linieritas kurva baku ditentukan dengan cara mengolah data konsentrasi seri kadar $(x)$ dan AUC (y) yang diperoleh dengan menggunakan persamaan regresi linier. Linieritas kurva baku baik jika nilai koefisien korelasinya $(r) \geq 0,999$ dan koefisien variasi regresi $\left(\mathrm{Vx}_{0}\right) \leq 5 \%$ bila nilai $r$ belum mencapai 0,999 (Anonim, 2002 ${ }^{\mathrm{a}}$ ).

\section{Pengujian presisi}

Pengujian presisi yang dilakukan adalah keterulangan (repeatability) sebagai variasi dalam sehari. Kadar yang digunakan dalam pengujian presisi adalah 200 ppm untuk rifampicin dan INH serta 400 ppm untuk pirazinamid. Ditotolkan pada plat silika gel $60 \mathrm{~F}_{254}$ dengan volume $2 \mu \mathrm{L}$ sebanyak 6 spot ripitasi dengan menggunakan linomat, dielusi dengan eluen terbaik dan dikeringkan, spot dalam plat silika kemudian dianalisis dengan densitometer. Data yang akan diperoleh adalah nilai $\mathrm{Rf}$ dan AUC kemudian dihitung nilai rata-rata $(\overline{\mathrm{x}})$,standar deviasi (SD) dan standar deviasi relatif (RSD). Berdasarkan AOAC, nilai presisi senyawa dengan konsentrasi 100-1000 ppm baik jika \% RSD-nya $\leq 4 \%$ (Anonim, 2002 ${ }^{\mathrm{a}}$ ).

\section{Penentuan batas deteksi dan batas kuantitasi}

Batas deteksi dan batas kuantitasi ditentukan dari regersi kurva baku yang diperoleh. Nilai LOD $=3,3 \times(\mathrm{SD} / \mathrm{S})$ dan $\mathrm{LOQ}=10 \times(\mathrm{SD} / \mathrm{S})$, standar deviasi $(\mathrm{SD})$ respon ditentukan berdasarkan standar deviasi residual (simpangan baku residual) dari garis regresi yang dinyatakan sebagai Sy/x dan $S$ merupakan nilai kemiringan (slope atau b) pada persamaan garis atau regresi linier $\mathrm{y}=\mathrm{bx}+\mathrm{a}($ Anonim, 2002 $\mathrm{a}$.

\section{Pengujian akurasi}

Akurasi ditentukan dengan menggunakan metode standar adisi. Sampel yang dianalisis mengandung 150 ppm rifampicin, 75 ppm INH dan 400 ppm pirazinamid. Sampel ditambahkan dengan 3 seri kadar standar yang berbeda yaitu 50 , 200 dan 400 ppm untuk rifampicin dan INH serta 100, 400 dan 800 ppm untuk pirazinamid. Kadar standar yang ditambahkan ke dalam sampel diharapkan dapat mewakili kadar terendah sampai kadar paling tinggi dari kurva baku yang digunakan. Ditotolkan pada plat silika gel 60 $\mathrm{F}_{254}$, masing-masing kadar 3 kali penotolan dengan volume penotolan masing-masing 2 $\mu \mathrm{L}$ dan dielusi dengan eluen terbaik. Spot pada plat silika kemudian dianalisis dengan densitometer dan akan diperoleh data berupa nilai AUC sampel yang telah ditambahkan standar kemudian dihitung \% perolehan kembali dari masing-masing kadar standar yang ditambahkan dalam sampel dengan menentukan persen analit yang ditambahkan yang dapat terukur. Berdasarkan AOAC, nilai \% perolehan kembali senyawa dengan konsentrasi 10 100 ppm baik jika nilainya 80-115 \% dan konsentrasi 100-1000 ppm nilainya antara 85-110\% (Anonim, 2002 ${ }^{\mathrm{a}}$ ).

\section{Preparasi larutan sampel}

Ditimbang 3 tablet sampel $X$ yang mengandung $150 \mathrm{mg}$ rifampicin $75 \mathrm{mg} \mathrm{INH}$ dan $400 \mathrm{mg}$ pirazinamid, digerus hingga halus. Dibuat stok sampel dengan konsentrasi 750 ppm rifampicin, 375 ppm INH dan 2000 ppm pirazinamid, dengan cara menimbang 0,04025 g sampel, dilarutkan dalam metanol $5 \mathrm{~mL}$, di-ultrasonic selama 5 menit, disaring dengan kertas Whatman dan dimasukkan ke dalam labu takar 10,0 mL, 
ditambah dengan metanol hingga $10,0 \mathrm{~mL}$ dan di-ultrasonic kembali selama 5 menit.

\section{Analisis kadar obat dalam sampel}

Sampel ditotolkan pada plat silika

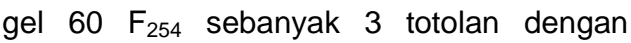
volume $2 \mu \mathrm{L}$, kemudian dimasukkan dalam chamber untuk dielusi dengan eluen terbaik sampai batas yang ditentukan yaitu $1 \mathrm{~cm}$ dari atas plat. Setelah dikeringkan, spot dalam plat silika dianalisis dengan densitometer dan akan diperoleh data berupa nilai AUC dari sampel. Perhitungan kadar sampel dilakukan dengan memasukkan nilai AUC sampel ke persamaan regresi linier dari kurva baku, $y=$ bx + a. Nilai y merupakan AUC sampel, $x$ adalah konsentrasi/kadar, b merupakan slope/kemiringan dan a adalah intersep (Ali, et al., 2007).

\section{HASIL DAN PEMBAHASAN}

Pengembangan dan validasi metode KLTDensitometri untuk menganalisis senyawa rifampicin, isoniazid $(\mathrm{INH})$ dan pirazinamid diawali dengan tahapan optimasi eluen atau fase gerak untuk menentukan eluen terbaik yang dapat memisahkan ketiga senyawa tersebut. Optimasi terkait kondisi awal dalam pengembangan metode dilakukan supaya diperoleh kondisi awal yang optimal. Hasil optimasi eluen menunjukkan eluen 9 yang terdiri dari campuran n-heksan: 2-propanol: aseton: amonia: asam format dengan perbandingan $\quad 3: 3,6: 3: 0,3: 0,1 \quad(\mathrm{v} / \mathrm{v} / \mathrm{v} / \mathrm{v})$ merupakan eluen terbaik yang dapat memisahkan ketiga senyawa yang dianalisis dengan sempurna dan nilai $\mathrm{Rf}$ yang dihasilkan relatif konstan saat dilakukan elusi ulang dengan eluen tersebut sesuai dengan Tabel 2.

Tabel 2. Keterangan hasil pemisahan senyawa rifampicin, INH dan pirazinamid dalam sediaan FDC OAT menggunakan eluen nomor 1- 10

\begin{tabular}{ccccc}
\hline \multirow{2}{*}{ Eluen } & Pemisahan spot rifampicin-INH- & \multicolumn{3}{c}{ Rf } \\
& pirazinamid & Rifampicin & INH & Pirazinamid \\
\hline 1 & Tidak terpisah & - & - & - \\
2 & Tidak terpisah & - & - & - \\
3 & Tidak terpisah & 0,1 & 0,6 & - \\
4 & Terpisah 2 analit & 0,3 & 0,7 & - \\
5 & Terpisah 2 analit & 0,6 & 0,7 & - \\
6 & Terpisah 2 analit & 0,75 & 0,85 & - \\
7 & Terpisah 2 analit & 0,75 & 0,7 & 0,8 \\
8 & Terpisah tidak sempurna & 0,9 & 0,6 & 0,75 \\
9 & Terpisah sempurna & 0,8 & 0,6 & 0,7 \\
10 & Terpisah sempurna & &
\end{tabular}




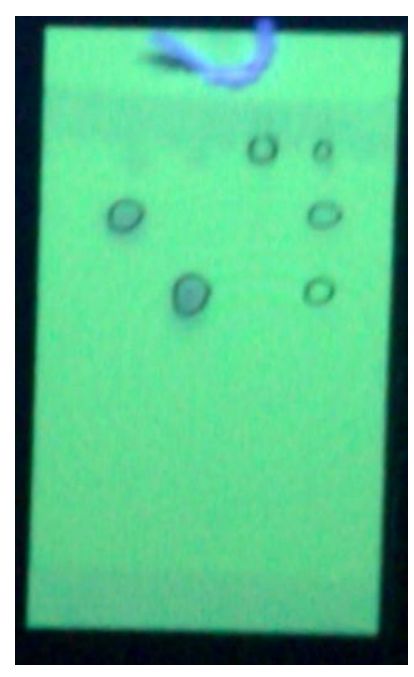

(a)

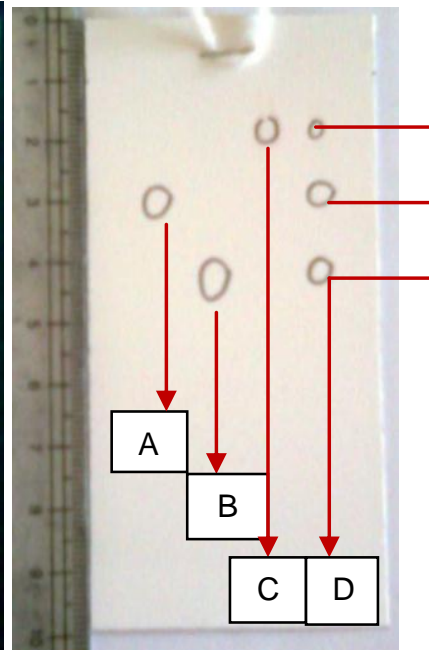

(b)

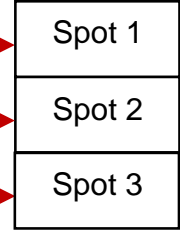

Keterangan

A: standar pirazinamid;

$\mathrm{B}$ : standar INH;

C: standar rifampicin;

D: sampel

Fase diam : silika gel $60 \mathrm{~F}_{254}$ Fase gerak : eluen no. 9

Pengembangan : menaik

Penotolan : $2 \mu \mathrm{L}$

Deteksi : UV $254 \mathrm{~nm}$

Gambar 2. Hasil kromatogram sampel FDC dibandingkan dengan standar tunggal rifampicin, INH dan pirazinamid yang dilihat di bawah sinar UV $254 \mathrm{~nm}$ (a) dan sinar tampak (b).

Berdasarkan keterangan hasil uji kualitatif sampel yang dianalisis pada Tabel 3 , dapat dinyatakan bahwa spot 1 identik dengan standar rifampicn, spot 2 identik dengan standar pirazinamid dan spot 3 identik dengan standar $\mathrm{INH}$, sehingga dapat disimpulkan bahwa sampel yang dianalisis diduga mengandung rifampicin, INH dan pirazinamid dengan adanya persamaan nilai Rf dan warna spot yang dilihat dibawah sinar UV $254 \mathrm{~nm}$ dengan masing-masing standar dari senyawa tersebut.

Tabel 3. Keterangan hasil uji kualitatif sampel FDC OAT dibandingkan dengan standar tunggal rifampicin, INH dan pirazinamid

\begin{tabular}{|c|c|c|c|c|c|c|c|}
\hline \multirow{3}{*}{ No. } & \multirow{3}{*}{$\begin{array}{l}\text { Parameter } \\
\text { identifikasi }\end{array}$} & \multicolumn{6}{|c|}{ Spot yang teridentifikasi } \\
\hline & & \multicolumn{3}{|c|}{ Sampel } & \multicolumn{3}{|c|}{ Standar } \\
\hline & & Spot 1 & Spot 2 & Spot 3 & Rifampicin & INH & Pirazinamid \\
\hline 1. & Nilai Rf & 0,85 & 0,7 & 0,6 & 0,85 & 0,6 & 0,7 \\
\hline 2. & $\begin{array}{c}\text { Warna bercak } \\
\text { pada UV } 254 \\
\mathrm{~nm}\end{array}$ & $\begin{array}{c}\text { Kuning } \\
\text { kemerahan }\end{array}$ & Ungu & Ungu & $\begin{array}{c}\text { Kuning } \\
\text { kemerahan }\end{array}$ & Ungu & Ungu \\
\hline
\end{tabular}

$\begin{array}{lll}\text { Keterangan } & : & \\ \text { Rf } & : & \text { Retardation factor } \\ \text { UV } & : & \text { Ultra violet }\end{array}$

Tahap penelitian selanjutnya adalah validasi metode analisis meliputi pengukuran linieritas kurva baku, presisi, batas deteksi, batas kuantitasi dan akurasi yang hasilnya akan dibandingkan dengan persyaratan yang tertera dalam Association of Official
Analytical Chemist (AOAC). Kurva baku dengan linieritas yang baik dapat digunakan untuk menetapkan kadar sampel yang kadarnya diperkirakan masuk dalam range kurva baku yang digunakan. 


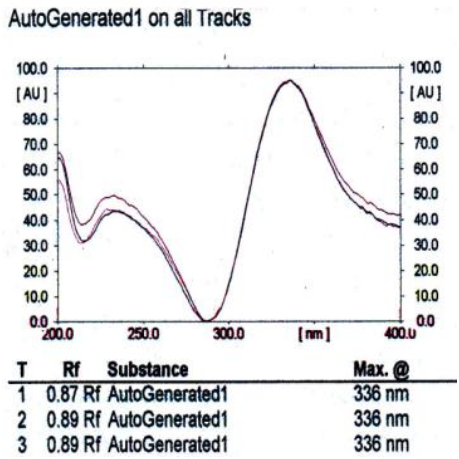

(a)

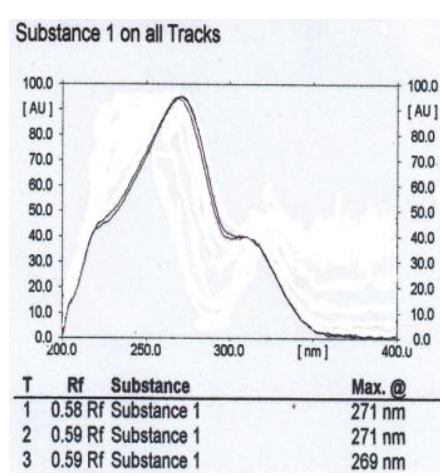

(b)

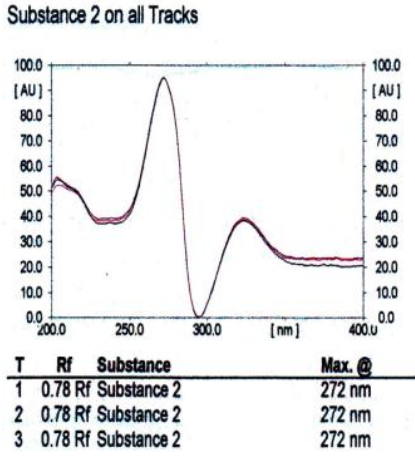

(c)

Gambar 3. Hasil optimasi panjang gelombang senyawa (a) rifampicin , (b) INH , (c) Pirazinamid pada densitometer

\section{Optimasi panjang gelombang maksimal $(\lambda$ max)}

Optimasi panjang gelombang maksimal ( $\lambda$ max) dari masing-masing senyawa bertujuan untuk mendapatkan senyawa yang spesifik dengan absorbansi yang maksimal sehingga pengukuran kadar yang diperoleh juga maksimal. Spesifisitas suatu metode analisis merupakan kemampuan suatu metode analisis untuk mengukur analit yang dituju secara tepat dan spesifik dengan adanya komponenkomponen matriks sampel seperti adanya pengganggu. Tujuan penentuan spesifisitas dalam penelitian ini dapat sebagai uji identifikasi. Sebagai uji identifikasi karena dapat membedakan antar senyawa yang mempunyai struktur molekul hampir sama terutama INH dan pirazinamid.

Hasil optimasi $\lambda$ max yang dapat dilihat pada Gambar 3 menunjukkan bahwa rifampicin, INH dan pirazinamid memiliki $\lambda$ max yang berbeda. Rifampicin dapat berpendar dengan optimal pada panjang gelombang $336 \mathrm{~nm}$, untuk INH pada panjang gelombang 269 sampai $271 \mathrm{~nm}$, sedangkan pirazinamid dapat berpendar dengan optimal pada panjang gelombang $272 \mathrm{~nm}$.

\section{Linieritas kurva baku}

Linieritas suatu metode analisis dinilai dengan cara menentukan grafik respon terhadap kadar, koefisien korelasi $(r)$ dari persamaan garis regresi, dan standar deviasi residual $(\mathrm{S} y / \mathrm{x})$ dari garis regresi (Ermer, et al., 2005). Standar deviasi residual ini akan digunakan untuk menghitung koefisien variasi regresi $\left(\mathrm{Vx}_{0}\right)$. Nilai $\mathrm{V} \mathrm{x}_{0}$ yang direkomendasikan adalah $\leq 5$ $\%$, jika koefisien korelasi yang diperoleh dari persamaan regresi linier belum mencapai 0,999 supaya suatu metode analisis tetap dapat dikatakan memiliki linieritas yang baik. $\mathrm{ICH}$ merekomendasikan minimal menggunakan 5 konsentrasi kadar dalam kurva baku untuk pengujian linieritas kurva baku suatu metode analisis (Kenkel, 2000). Hasil pengukuran kurva baku rifampicin, INH dan pirazinamid menggunakan larutan stok baku campuran dapat dilihat pada Tabel 4 .

Tabel 4. Persamaan regresi linier kurva baku Rifampicin, INH dan Pirazinamid

\begin{tabular}{ccccc}
\hline No & $\begin{array}{c}\text { Nama } \\
\text { senyawa }\end{array}$ & Seri kadar $(\mathbf{p p m})$ & Nilai $\mathbf{r}$ & $\begin{array}{c}\text { Persamaan } \\
\text { regresi linier }\end{array}$ \\
\hline 1. & Rifampicin & $50,100,200,300,400$ & 0,999 & $\mathrm{y}=0,994 \mathrm{x}+9,672$ \\
2. & INH & $50,100,200,300,400$ & 0,999 & $\mathrm{y}=0,996 \mathrm{x}+1,942$ \\
3. & Pirazinamid & $100,200,400,600,800$ & 0,999 & $\mathrm{y}=1,005 \mathrm{x}+140,7$ \\
\hline
\end{tabular}


Berdasarkan hasil pada Tabel 4, dapat disimpulkan bahwa linieritas kurva baku rifampicin, INH dan pirazinamid memenuhi persyaratan yang baik sehingga dijamin validitasnya. Pengukuran kadar sampel yang mengandung rifampicin, INH dan pirazinamid dengan menggunakan persamaan regresi dari kurva baku di atas dapat dijamin validitasnya ketika kadar sampel masuk dalam range kurva baku, apabila kadarnya melebihi atau di bawah range kurva baku maka hasil pengukuran dengan menggunakan persamaan regresi di atas tidak dijamin validitasnya.
Batas deteksi didefinisikan sebagai konsentrasi analit terendah dalam sampel yang masih dapat dideteksi, meskipun tidak selalu dapat dikuantitasi. Batas kuantitasi merupakan konsentrasi analit terendah dalam sampel yang dapat ditentukan dengan presisi dan akurasi yang dapat diterima pada kondisi operasional metode yang digunakan. Batas deteksi dan batas kuantitasi merupakan parameter sensitivitas suatu metode analisis, semakin kecil nilai batas deteksi dan kuantitasi menandakan semakin sensitif suatu metode dalam menganalisis dan mengukur kadar suatu analit.

Batas deteksi (Limit of Detection, LOD)

dan batas kuantitasi (Limit of

Quantitation, LOQ)

Tabel 5. Nilai batas deteksi dan kuantitasi rifampicin, INH dan pirazinamid

\begin{tabular}{cccc}
\hline No. & Nama senyawa & Nilai batas deteksi (ppm) & Nilai batas kuantitasi (ppm) \\
\hline 1. & Rifampicin & 10,91 & 33,07 \\
2. & INH & 10,38 & 31,45 \\
3. & Pirazinamid & 42,14 & 127,7 \\
\hline
\end{tabular}

\section{Presisi (keseksamaan)}

Presisi merupakan ukuran kedekatan antara serangkaian hasil analisis yang diperoleh dari beberapa kali pengukuran pada sampel homogen yang sama. Presisi biasanya diekspresikan sebagai simpangan baku relatif dari sejumlah sampel yang berbeda sigifikan secara statistik. Keterulangan merupakan ketepatan pada kondisi percobaan yang sama (berulang) baik analisnya, peralatannya, tempatnya, maupun waktunya, sedangkan presisi antara merupakan ketepatan pada kondisi percobaan yang salah satunya berbeda baik analisnya, peralatannya, tempatnya maupun waktunya.
Dokumentasi presisi seharusnya mencakup simpangan baku, simpangan baku relatif (RSD) atau koefisien variasi (CV). Merujuk pada Association of Official Analytical Chemist (AOAC) Guidelines yang merupakan acuan dalam validasi metode analisis, nilai RSD presisi keterulangan yang diterima untuk senyawa dengan kadar 100 sampai 1000 ppm adalah tidak lebih dari $4 \%$ (Anonim, 2002 ${ }^{\mathrm{a}}$.

Hasil pengukuran presisi untuk semua komponen telah memenuhi persyaratan dari AOAC sehingga dapat dikatakan metode yang dikembangkan telah memenuhu kriteria yang ditentukan dan hasil pengukuran presisi disajikan dalam Tabel 6 . 
Tabel 6. Hasil pengukuran presisi keterulangan (repeatibility atau intraday precision) rifampicin dan INH dengan konsentrasi 200 ppm serta pirazinamid 400 ppm dalam larutan baku campuran

\begin{tabular}{ccccccc}
\hline \multirow{2}{*}{ No. $^{*}$} & \multicolumn{2}{c}{ Rifampicin } & \multicolumn{2}{c}{ INH } & \multicolumn{2}{c}{ Pirazinamid } \\
\cline { 2 - 7 } & $\mathbf{R f}$ & $\mathbf{A U C}$ & $\mathbf{R f}$ & $\mathbf{A U C}$ & $\mathbf{R f}$ & AUC \\
\hline 1. & 0,91 & 4189,20 & 0,61 & 7166,60 & 0,80 & 13195,60 \\
2. & 0,95 & 4412,20 & 0,61 & 7105,00 & 0,80 & 13084,10 \\
3. & 0,95 & 4454,30 & 0,61 & 7110,80 & 0,80 & 13087,00 \\
4. & 0,94 & 4437,90 & 0,60 & 7016,70 & 0,80 & 13082,80 \\
5. & 0,93 & 4420,20 & 0,60 & 7076,10 & 0,79 & 13055,00 \\
6. & 0,92 & 4475,00 & 0,60 & 7138,30 & 0,79 & 13113,70 \\
$\bar{X}$ & 0,93 & 4398,13 & 0,61 & 7120,25 & 0,80 & 13103,03 \\
SD & 0,02 & 104,86 & 0,01 & 52,01 & 0,01 & 49,02 \\
\hline RSD (\%) & $\mathbf{1 , 7 2}$ & $\mathbf{2 , 3 8}$ & $\mathbf{0 , 8 3}$ & $\mathbf{0 , 7 3}$ & $\mathbf{0 , 6 3}$ & $\mathbf{0 , 3 7}$ \\
\hline
\end{tabular}

\section{Akurasi}

Akurasi merupakan kedekatan antara nilai terukur dengan nilai yang diterima sebagai nilai sebenarnya. Akurasi dinyatakan sebagai persen perolehan kembali (recovery) analit yang ditambahkan. Pengukuran akurasi dalam penelitian ini menggunakan metode standar adisi, karena sampel yang dianalisis merupakan obat paten yang tidak diketahui matriks didalamnya sehingga tidak memungkinkan untuk membuat sampel plasebonya. Metode adisi merupakan teknik analisis kuantitatif dengan menambahkan sejumlah analit dengan jumlah yang telah diketahui ke dalam sampel. Persen perolehan kembali ditentukan dengan menentukan berapa persen analit yang ditambahkan tadi dapat ditemukan. Suatu pendekatan praktik dalam metode standar adisi adalah dengan membagi sampel ke dalam beberapa bagian yang sama lalu menambahkan ke dalamnya standar dengan level konsentrasi yang meningkat. Merujuk persyaratan nilai akurasi yang tertera dalam AOAC, nilai akurasi yang diterima untuk konsentrasi 10 sampai 100 ppm adalah 80-115 \% dan untuk konsentrasi 100 sampai 1000 ppm adalah 85-110\%.

Tabel 7. Nilai akurasi (\% perolehan kembali) Rifampicin, INH, Pirazinamid yang diukur pada 3 konsentrasi yang berbeda

\begin{tabular}{cccc}
\hline No. & Senyawa & Level & Recovery (\%) \\
\hline \multirow{2}{*}{ 1. } & \multirow{2}{*}{ Rifampicin } & $80 \%$ & 97,44 \\
& & $100 \%$ & 101,00 \\
& & $120 \%$ & 106,71 \\
2. & \multirow{2}{*}{ INH } & $80 \%$ & 105,45 \\
& & $100 \%$ & 94,36 \\
& & $120 \%$ & 100,18 \\
3. & \multirow{2}{*}{ Pirazinamid } & $80 \%$ & 95,48 \\
& & $100 \%$ & 85,94 \\
\hline
\end{tabular}

Berdasarkan hasil akurasi dari rifampicin, INH dan pirazinamid yang tertera pada Tabel 7 diketahui persen perolehan kembali dari ketiga senyawa tersebut memenuhi persyaratan yang tertera dalam AOAC, sehingga dapat ditarik kesimpulan bahwa metode KLT-Densitometri yang digunakan untuk menganalisis senyawa tersebut memiliki tingkat ketelitian yang baik karena dapat menghasilkan nilai pengukuran kadar analit yang sangat dekat dengan nilai sebenarnya. Ketelitian metode analisis yang baik akan memberikan hasil yang akurat saat metode tersebut digunakan untuk 
mengukur kadar sampel yang dianalisis, sehingga hasilnya dapat dijamin kebenarannya. Oleh karena itu, dapat disimpulkan bahwa metode KLTDensitometri ini memiliki validitas yang baik berdasarkan hasil pengukuran akurasi yang nilainya yang memenuhi persyaratan dalam AOAC.

\section{Penetapan Kadar Sampel}

Penetapan kadar sampel merupakan tahap akhir yang dilakukan dalam penelitian setelah metode baru yang dikembangkan memiliki validitas yang baik sehingga hasil pengukurannya dapat dipertanggungjawab kan kebenarannya.

Tabel 8. Hasil pengukuran kadar rifampicin, INH dan pirazinamid dalam sampel FDC OAT dengan metode KLT-Densitometri

\begin{tabular}{|c|c|c|c|c|}
\hline \multirow{2}{*}{ No. } & \multirow{2}{*}{ Nama sampel } & \multicolumn{3}{|c|}{ Nilai AUC } \\
\hline & & Rifampicin & INH & Pirazinamid \\
\hline 1. & Replikasi 1 & 1987,30 & 1838,40 & 11797,40 \\
\hline 2. & Replikasi 2 & 1996,10 & 1854,70 & 11696,50 \\
\hline 3. & Replikasi 3 & 2242,80 & 1843,20 & 11558,10 \\
\hline & ata-rata & 2075,40 & 1845,43 & 11684,00 \\
\hline $\mathrm{Ka}$ & terukur (ppm) & 157,37 & 75,26 & 400,79 \\
\hline $\mathrm{Ka}$ & terukur (mg) & 157,37 & 75,26 & 400,79 \\
\hline
\end{tabular}

USP mensyaratkan kadar sampel dalam sediaan yang mengandung rifampicin, INH dan pirazinamid adalah antara 90 sampai 110 \% (Kenyon, et al., 1999). Hasil pengukuran kadar sampel yang dapat dilihat pada Tabel 8 menunjukkan bahwa sampel yang dianalisis memilki kadar yang sesuai dengan nilai sebenarnya yang tertera dalam kemasan produk dan persyaratan yang ditetapkan dalam USP, sehingga dapat disimpulkan sampel FDC yang mengandung $150 \mathrm{mg}$ rifampicin, $75 \mathrm{mg} \mathrm{INH}$ dan $400 \mathrm{mg}$ pirazinamid tidak subdosis ataupun melebihi dari dosis yang ditetapkan.

Bila sediaan FDC OAT subdosis akan menyebabkan pengobatan TB menjadi tidak optimal karena dosis yang dibutuhkan untuk dapat mengobati penyakit ini tidak cukup sehingga tidak dapat membunuh bakteri penyebab penyakit TB dan apabila dosis sediaan FDC OAT ini melebihi dari dosis yang ditentukan dapat menyebabkan risiko toksisitas dari OAT tersebut. Subdosis ataupun melebihi dari dosis pada sediaan FDC OAT ini keduanya dapat meningkatkan risiko resistensi antibiotik yang mengakibatkan pengobatan TB menjadi kurang optimal.

Hasil pengukuran kadar sampel yang mengandung rifampicin, INH dan pirazinamid pada sediaan FDC OAT menunjukkan hasil bahwa masing-masing kadar senyawa tersebut memenuhi persyaratan kadar dalam USP dan sesuai dengan kadar yang tertera pada kemasan produk, sehingga diharapkan dengan sesuainya dosis sediaan FDC OAT ini dapat memberikan hasil pengobatan penyakit TB yang optimal dan menurunnya angka resistensi OAT pada pasien TB.

\section{KESIMPULAN}

Pengembangan metode analisis dengan KLT-Densitometri telah dilakukan untuk menganalisis senyawa rifampicinisoniazid (INH)-pirazinamid dalam sediaan Fix Dose Combination (FDC) Obat Anti Tuberkulosis (OAT). Metode hasil pengembangan dapat memisahkan senyawa yang dianalisis dengan sempurna dan 
memiliki validitas yang baik karena semua hasil penilaian parameter validasi memenuhi persyaratan yang ditetapkan oleh Association of Official Analytical Chemist (AOAC). Kadar sampel FDC OAT yang mengandung rifampicin, INH dan pirazinamid yang terukur sesuai dengan kadar yang tertera dalam kemasan sampel dan persyaratan yang ditetapkan oleh United State Pharmacopoeia (USP).

\section{DAFTAR PUSTAKA}

Anonim, 2002 ${ }^{\mathrm{a}}$, AOAC Guidelines for Single Laboratory Validation of Chemical Methods for Dietary Supplements and Botanicals, available at http://www. AOAC.org (diakses 12 Desember 2009).

Anonim, 2002 ${ }^{\mathrm{b}}$, Informal consultationon 4drug Fixed-Dose Combinations (4FDCs) compliant with the WHO Model List of Essential Drugs, World Health Organization, Geneva Switzerland.

Anonim, 2006, United State Pharmacopoeia 30-National Formulary 25, USA, available at http://www.usp.org (Diakses 10 April 2007).

Anonim, 2008, Lembar Fakta Tuberkulosis, Departemen Kesehatan Republik Indonesia, Jakarta.

Ali, J, N. Ali., Y. Sultana., S.Baboota., and S. Faiyas., 2007, Development and Validation of A Stability-Indicating HPTLC Method for Analysis of Antitubercular Drugs, Acta Chromatographica, 18: 168-179.

Kelesidis, K., Kelesidis, L., Rafailidis, P., Falagas, M., 2007, Counterfeit or substandard antimicrobial drugs: a review of the scientific evidence, $J$. Antimicrob. Chem, 60: 214-236.

Kenkel, J., 2000, A Primer on Quality in the Analytical Laboratory, Lewis Publishers, Boca Raton Florida, 9.
Kenyon, A.S., 1999, Rapid sreening of TB Pharmaceutical by Thin-Layer Chromatography, Food and Drug Administration, Division of Testing and Applied Analytical Development, St. Louis.

Kenyon, T.A., Kenyon, A.S., Kgarebe, B.V., Mothibedi, D., Binkin, N.J., Layloff, T.P., 1999, Detection of Substandard Fixed-Dose Combination Tuberculosis Drugs Using Thin Layer Chromatogtaphy, Int. J. Tuberc. Lung. Dis, 11: S347S350.

Khuhawar, M.Y., and Rind, F., 1998, High Performance Liquid Chromatographic Determination of Isoniazid, Pyrazinamide and Rifampicin in Pharmaceutical Preparation, P. J. Pharm. Sci., II: 49-54.

Ermer, J., and Miller, J., 2005, Method Validation in Pharmaceutical Analysis A Guide to Best Practice, Wiley-VCH Gmbh \& Co. KgaA, Weinheim, 3, 248-249.

Peloquin, C.A., 2007, Tuberculosis; in Dipiro, et al (Eds): Pharmacotherapy A pathophysiological approach, McGraw-Hill, New York, 2020-2024.

Rohman, A., 2007, Kimia Farmasi Analisis, Pustaka Belajar, Yogyakarta, 353366, 460-469. 